\title{
Features of THE MOdern EdUCATIONAL ENVIRONMENT FOR ENGINEERS
}

\author{
REBRIN, O. \& SHOLINA, I.
}

Abstract: New industry needs new quality of staffing. Modern engineers should be prepared for work under the increasing complexity of technological processes and equipment, rapidly changing requirements to competitive products, the need for continuous improvement of production efficiency.

An effective way of solving the problem of staffing in industrial enterprises is their active involvement in the educational process with the support of the government.

The article presents the main directions of the development of engineering education: the development and implementation of the partnership educational programs and new organizational forms; the technology of project-based learning and engineering competitions and tournaments.

In this article we describe the model of public-private partnership which is called a Professional Competence Centre (vocational education and training center) for Continuing professional development (CPD).

Key words: the partnership educational programs, learning outcomes, VET
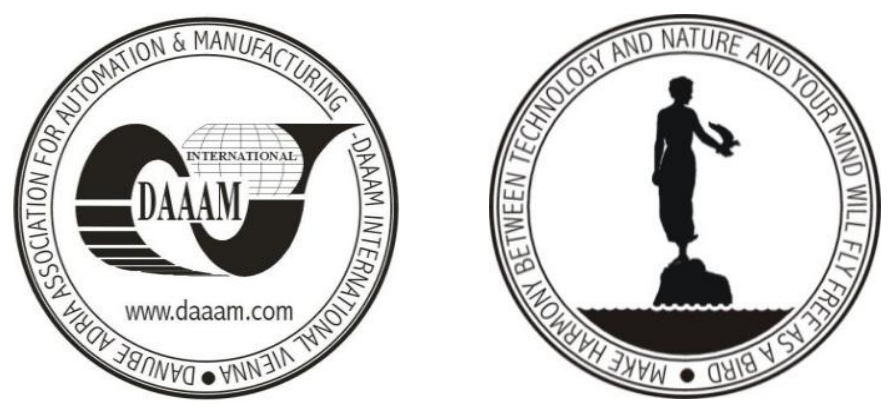

Authors' data: Univ.Prof. Dr. Sc. Rebrin, O[leg]; Sholina, I[rina], Ural Federal University, Mira, 21, Ekaterinburg, Russia, oirebrin@gmail.com, iisholina@gmail.com

This Publication has to be referred as: Rebrin, O[leg] \& Sholina, I[rina] (2014). Features of the Modern Educational Environment for Engineers, Chapter 40 in DAAAM International Scientific Book 2014, pp.501-508, B. Katalinic (Ed.), Published by DAAAM International, ISBN 978-3-901509-98-8, ISSN 1726-9687, Vienna, Austria

DOI: $10.2507 /$ daaam.scibook.2014.40 
Rebrin, O. \& Sholina, I.: Features of the Modern Educational Environment for Engi...

\section{Introduction}

The urgency of the task of revival and development of the Ural engineering school is determined by the need of promoting the development of Russia's industrial production, and to a large extent, typical for our region.

Modern engineers should be prepared for work under the increasing complexity of technological processes and equipment, rapidly changing requirements to competitive products, the need for continuous improvement of production efficiency.

In general, educational environment reflects the two basic principles of education that is fundamental and practice-oriented nature. The right balance between them determines the success of training and continuous improvement of technical experts' qualification.

The idea of building educational environment of continuing technical education that combines educational levels and different partners is taken as the basis for the revival and development of the Ural School of Engineering.

The successful cooperation in the development and implementation of educational programs requires certain organizational activity that is creating and testing models for public-private partnership in this area.

The studies conducted with the help methods of sociological diagnostics and social design have shown that implementation of educational programs requires new organization models.

According to the results of the studies, effectiveness of professional education can be increased by means of Professional competence centers (vocational education and training centers) equipped with university educational and scientific resources and located on the enterprise sites.

As these centers are located on the enterprises sites, they help to solve staffing and territory development problems.

Professional Competence Centre (Vocational education and training centre for lifelong learning) is an integrated model of public-private partnership for business, educational institutions, and government for continuing professional development (continuing professional education).

The Continuing professional development areas are created by building the contractual relationship between educational institutions of different levels (schools, institutions of secondary and higher vocational education), training centres or corporate universities on the area basis for the purpose of training staff for a large industrial enterprise or group of enterprises with the participation of public authorities.

\section{Important}

The main issue associated with the formation of human resources capacity in the Ural region, the region that is striving to take a leading position in the new technological order, is the lack of the system for lifelong learning. 
This issue involves many problems such as dissatisfaction of employers with graduates training, lack of coordination between the government, business and education in the formation of the national system of competences and qualifications, outdated research subjects and content of educational programs, inefficient educational technologies and others.

Numerous studies conducted on the development of human resources in the Ural region (Bannikova \& Sholina, 2013) allowed, on the one hand, to identify certain problems and, on the other hand, to analyse different ways for their solution. At the heart of all successful experiments, there is an express interest of industrial enterprises proved by their participation in the implementation of educational programs in schools, colleges and universities.

This article studies the main problem in training of technical elite, that is disintegration between the system of engineering education and science. For the empirical material we used statistical data of the scientific personnel and sociological monitoring of students and teachers of engineering specialties of Yekaterinburg universities.

One of the main problems of modernization of engineering education is the contradiction between the steady growth of the number of students in technical Universities and decrease in the number of researchers in technical departments. In other words there is contradiction between quantity and quality in training of professionals for innovative economy. The occupational groups of qualified specialists present the core of the structure of innovative employment and engineering elite.

What does the scientific staffing structure in the main branches of science serving key industries of the real economy and, in particular, engineering sciences look like? What is the proportion and qualifications of researchers designing new machines, equipment and processes, and participating in the creation of new engineering knowledge?

Training engineers-researchers with deep knowledge in definite areas, advanced creative abilities and skills for scientific work takes special place in training qualified specialists for innovative economy.

As you know, this form of activity is introduced on innovative platforms and in small businesses at universities, where students and teachers could approve and implement their business ideas and scientific developments, simultaneously solving their financial problems. We have to admit that innovative platforms and small businesses at universities remain a mystery to most of the university community: $60 \%$ of students are not aware of the possibility to participate in this work (Bannikova \& Vishnevsky 2013).

Students didn't express satisfaction regarding the involvement of engineering departments in the scientific activities. The students'opinion on broadening options in the area of scientific activities divided almost equally: 51\% said „yes“, $49 \%$ - „no“.

Revitalization of career guidance, development of scientific and technical creativity of youth is being actively discussed today by engineering and academic community. The study concluded that the existing models are not effective. 
The article describes the model of Professional Competence Centre - new form of Vocational education and training centre for lifelong learning, built in the competence-based ideology (Gibbs et all 2012), the use of the methodology of learning outcomes in the design and implementation of educational programmes (Rebrin 2013).

Employers are greatly interested in the opportunity to actualize the topics of universities' scientific researches and make them closer to the terms of reference of enterprises, in order to enable R\&D centers operate more effectively.

Professional Competence Centre have been put into operation in several large corporations.

Creation of Professional Competence Centre will enable to develop a constantly evolving system of continuing technical education, including total, secondary vocational, higher and further education, providing the industry with highly qualified personnel in the region.

Sverdlovsk region may act as a pilot site for the implementation of Professional Competence Centre as a new model of public-private partnership. These centers will become the main driving force for the formation of the modern educational environment for engineering training.

\section{Information}

The integration of educational organizations and employers is the main direction of the development of engineering education that may support the staffing requirements of industry. We will highlight two aspects of integration. The first is related to the development and implementation of the so-called partnership educational programs.

The partnership begins at a very early stage, at the stage of designing expected learning outcomes, a competency portrait of the future graduate of the program. Here the view of the employer, ideally formalized in professional standards, is crucial. Of course, the university expresses its own vision, and a specific forecast for the qualities of the future graduate, the so called educational foresight.

The second aspect of integration is relation to new organizational forms, the possibility of implementing them was opened by the Law on Education in the Russian Federation. First of all, it's basic academic departments that universities open on the premises of partner enterprises. One of the tasks of a basic academic department is practical training of students using technical capacity of the enterprise. Another but not less important task is to become a kind of interface between the university and the company for building not only educational, but also scientific contacts, it develops application of university research for the solution of industrial problems.

Professional Competence Centres combining on a contractual basis educational institutions of various levels and enterprise's training centres might become one of the organizational forms of integration for the solution of personnel problems of enterprises. 

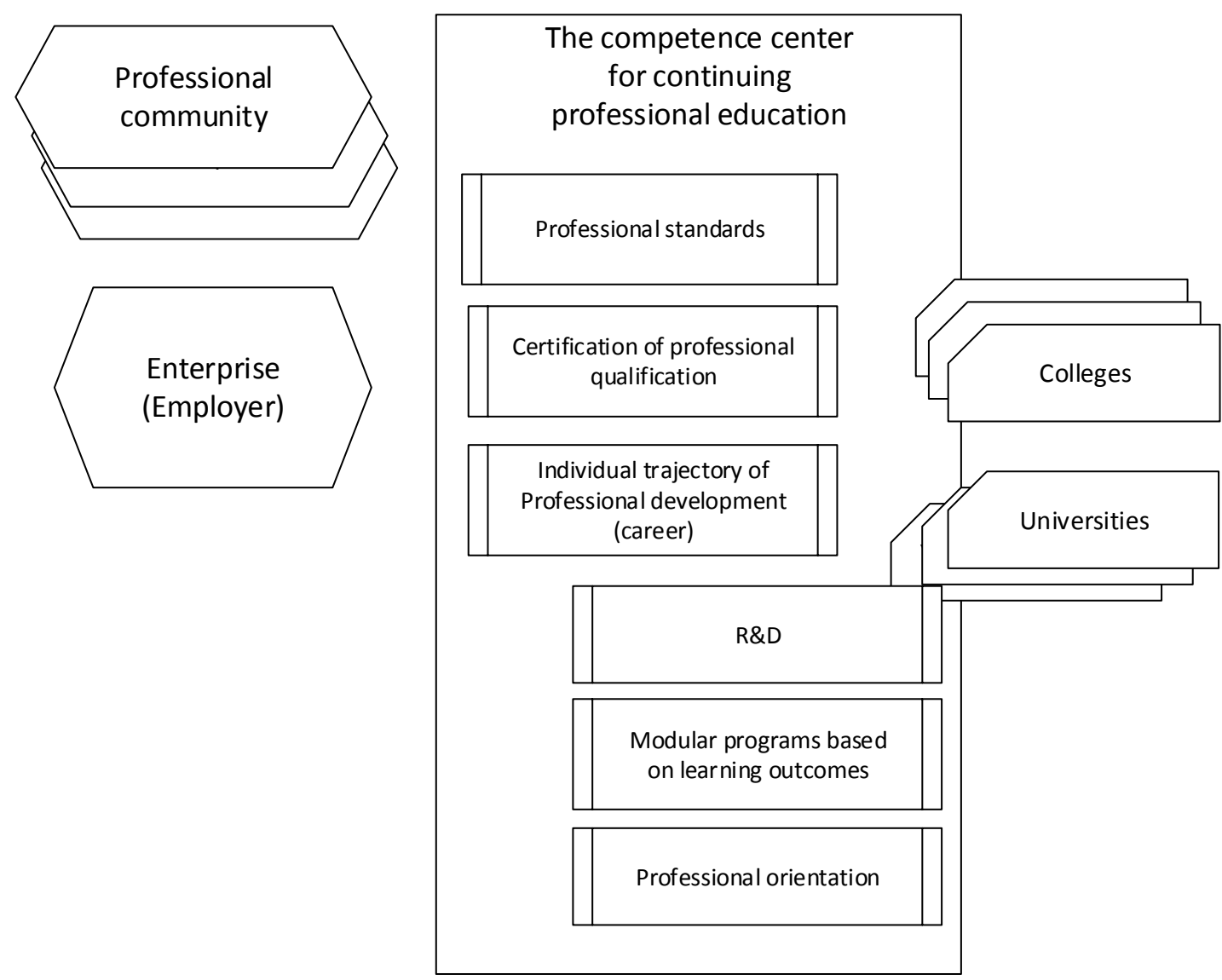

Fig. 1. Model of Professional Competence Centres

The scope of work, solved in professional staffing centres, is wide enough; it includes early motivation of students for technical education, training of personnel and specialists of different levels, adaptation of professional standards, certification of professional qualifications of graduates and staff, joint research and innovation activity. It's not enough to define proper learning outcomes, it's more important to achieve them. For this purpose one should apply modern educational technologies.

One of these innovations is the technology of project-based learning. The technology was well-known in the Soviet higher education, but undeservedly forgotten.

The core of the technology is implementation of educational projects of increasing complexity and small technical tasks by teams of students. It is this team work that forms the necessary leadership qualities and the ability to defend the idea and the responsibility for the decisions taken.

This approach is formalized today in the standards of the world-wide initiative CDIO (Conceive Design Implement Operate) and developed in a number of leading technical universities of Russia and the world. UrFU (Ural Federal University) joined the international project in 2013 and is an active participant in the initiative (Crawley et all 2011).

To demonstrate it we'll describe some of our new curricula, based on learning outcomes and educational projects. 
An example of a simple project (for example by creating an electric hoist) that however needs knowledge of engineering graphics, technical mechanics, strength of materials, materials science, electrical engineering, and even standardization and metrology.

As we move on courses, the complexity of tasks increases, they now have a specific character important for the production.

This is another side of the partnership, where specialists of industrial enterprises actively participate in the whole process: from the stage of setting a goal to accepting the results.

The projects aim is to master all the stages of the life cycle of engineering products and involve not only the calculation, but also the implementation of ideas into the "iron". But for this purpose it is necessary to create favourable environment, namely, equipped engineering laboratories, and it is also a task for the coordinated solution.

Organizing training and active participation of future engineers in various engineering competitions and tournaments both at regional and international levels, continue the theme of project-based teaching and learning.

This is a really effective way of training enthusiastic, talented and dedicated engineering professionals. Participation of leading industrial specialists as coaches (tutors) and jury members in such competitions ensures the continuity of generations, preserving the best traditions of the Urals School of Engineering.

Another area proposed for the development in the framework of the Program is to develop and implement educational programs that prepare general-engineers (the program's systems engineering) with a set of competencies required to manage the execution of complex technical projects.

The Higher School of Engineering, UrFU is planning to accept first students for studying in the Master's program this year. We are open for cooperation and look forward to the support and assistance.

Another important point is an adequate assessment of achievement of expected learning outcomes and efficiency of education.

Starting the process of professional and public accreditation of education engineering programs in the Urals is a relevant task today. Under the law, it is the prerogative of employers, their associations and their authorized organizations. Such an evaluation system for the quality and relevance of programs is developed by the educational institutions.

The next thing connected with quality assessment is certification of professional qualifications not only of graduates, but also operating engineers with some positive experience of independent work.

Rapid technological change and dynamic production tasks require constant retraining and advanced training of technicians. So building the system of lifelong learning, perhaps the most important one, is a crucial task.

In that context it is proposed to organize a permanent regional Governor's program for training engineering personnel. 
The proven success of the regional participation in the similar President's program might be taken as a basis for the initiative, of course, taking into account all the difficulties and shortcomings.

In conclusion, We wish to emphasize the importance of ensuring a smooth transferring of a young specialist from the university environment to the professional environment. To some extent, these problems will be solved with the development of the previously mentioned integration processes, but nevertheless.

\section{Conclusion}

Problems that caused huge wave of reforms in educational system in the whole world, at the end of last century, were determined by the transaction global economy to postindustrial phase.

The need of educational system's transformation in line with the dynamics of changing has led the attention to Vocational Education And Training (VET) (technical and vocational education and training (TVET), search of effective cooperation between education and busines (industry) and state to remove main nonconfornoties during the process of formation of competence system and qualifications.

Due to the formation of national competence system and qualifications was find a list of main problems (Bannikova \& Sholina 2013) that could be solved with help of development, integration and research of different types of partnership model.

The invariant that can be seen in different models and basic specific features were marked during to researches that were held on the approbation stage. Invariant is the single algorithm of coactions during the process of development professional standards, qualifications and professional education.

In this article CPD Centers (Continuing professional development centers) are model of state and private partnership. There are different types of constitutions (state, regional and federal), business structures (enterprises as state as private)

In future these centers can present concentration intellectual resources that will solve territory development problems, provide creation modern engineering infrastructure.

Introduced hypothesis is that the creation of Professional Competence Centre as state and private partnership that are clause to exact enterprises and territories can have positive influence on the solution of variety of problems:

- The problem of making (growth) of the national competence and qualification system. Main participants have lack of competence and information;

- There is no system of Continuing professional development for professional growth and the growth of qualification skills for the personnel of the company and engineering teams, they are ready for the modernization of the production through solving the problem of making rival product;

- The lack of International Competitiveness in the field of production and education; 
- There is the distance between researches of the scientific organization and the needs of the exact Productions;

- Lack of coordination in levels of education;

- Lack of qualified, adequate teachers in the field of modern educational technologies, in making and realization of educational programs.

Professional Competence Centre provides:

- Proximity of education to production;

- Realization of educational programs with more practice hours ;

- Actualization of educational programs, invitation of experts from production, dual education;

- Time reducing for preparing to professional activity;

- Motivation of the students with different levels of knowledge for getting the education, getting of exact profession;

- Promotion of developments of the University, that will solve present and future technical problems of production;

- Motivation of getting education in the interest of the company;

- Participation of regional and federal state authority and companies as private as public is the effective model.

\section{References}

Bannikova L.N., Sholina I.I., Problems of formation of engineering elite of the industrial region. Society and power in 2013, № 5 (43) The scientific journal, ISSN 1996-0522, the publishing house of the Chelyabinsk Institute (branch) FSEIHPE "Ural Academy of Public Service," included in the list of journals WAC, S. 86-90 Bannikova LN, Vishnevsky YR Formation of engineering elite of the industrial region: a sociological analysis / ed. - Yekaterinburg Yekaterinburg: the publishing house of the Ural University, 2013. 216 p. Department IGUP (Grant) ISBN 978-57996-1067-8

Edward F. Crawley, Johan Malmqvist, William A. Lucas, Doris R. Brodeur. The CDIO Syllabus v2.0. An Updated Statement of Goals for Engineering Education. Proceedings of the 7th International CDIO Conference, Technical University of Denmark, Copenhagen. 2011. June 20-23. CDIO

Gibbs A., Kennedy D. and Vickers A. Learning Outcomes, Degree Profiles, Tuning Project and Competences. - Journal of the European Higher Education Area. 2012. № 15 (5). P. 71-87

Rebrin O.I. The use of learning outcomes in the design of educational programs UrFU / Ed. 2nd, ext. - Yekaterinburg: LLC "Publishing House" Ajour "2013 - 32 Rebrin O.I., Sholina I.I., Tretyakov V.S. (2014) Technological modernization of higher education. - Yekaterinburg: LLC "Publishing House" Ajour "2014 - 40. ISBN 978-5-91256-183-2 